\title{
Role of some Factors Affecting Crown Gall Disease Development
}

Barakat, F.M. ${ }^{1}$; Mikhail, M.S. ${ }^{1}$; Tawfik, A.E. ${ }^{2}$ and Abd-El-Aziz, R.M. ${ }^{2}$

1- Department of Plant Pathology, Faculty of Agriculture, Cairo University, Giza, Egypt.

2- Plant Pathology Research Institute, Agricultural Research Center, 12619, Giza, Egypt

The wounds, its depth and the time of inoculation of Agrobacterium tumefaciens on castor bean (Ricinus communis) plants affecting on the development of apricot crown gall disease whereas, the increase of wound depth and adding the pathogen after directly wounding plants increased the disease severity and gall formation. Where, the highest infection and gall formation resulted from inoculation of $A$. tumefaciens after directly wounding plants (zero time) at $3 \mathrm{~mm}$ depth followed by $5 \mathrm{~mm}$ depth, while the lowest gall formation and disease severity showed when adding $A$. tumefaciens suspension after $48 \mathrm{hrs}$. from wounding at one $\mathrm{mm}$ depth. On apricot plants (Prunus armeniaca), The plant hormones indole acetic acid (IAA) and cytokinin (CK) were decreased in the first stage of gall formation, while they were increased in the other stages of gall formation. Gibberellic acid (GA) was decreased in the first stage and then increased but it decreased again in the last stage.

On the other hand, abscisic acid (ABA) inactivation plant hormone showed an opposite result whereas, ABA was increased in the first stage of gall formation and then it was decreased in the other stages of disease. Also, A. tumefaciens isolates obtained from different hosts having different gall index (different in virulence) produced different rates of plant hormones IAA, GA, ABA and CK. But the rate of CK was found to be correlated with virulence. Also, crown gall disease development dependent on the production amount of the three plant hormones (IAA, GA3 and CK) and the ratio between them.

Fertilizers with (NPK) and compost resulted in decrease the severity of crown gall disease on apricot plants whereas; they reduced the number and weight of galls and root gall index in the treated plants compared with control. The best one treatment was (NPK) then (NP) and (NPK plus compost). Fertilizers with (NPK plus compost) due to increase the foliage of plants and in all fertilizer treatments increased the roots of plants compared with control except that treated with (NP). Also, no variation considered in the height of plants in all treatments, but the highest height recorded from (NPK plus compost) treatment. On the other hand, the uptake of $(\mathrm{N})$ was increased in all fertilizers when used $(\mathrm{N})$ alone or in combination with (P or $\mathrm{K})$, also, (P) up take increased when used $(\mathrm{P})$ alone or with $(\mathrm{N}$ or $\mathrm{K})$. But $(\mathrm{K})$ up take was increased only when used it with $(\mathrm{N})$ or $(\mathrm{P})$ and in combination with (NPK).

Keywords: Apricot, Prunus sect. Armeniaca, Crown-gall, Agrobacterium tumefaciens, disease severity, compost, NPK fertilizers, Indole acetic acid and Cytokinin. 
Production of growth regulator, wounds, its depth, and mineral fertilizers, affecting the development of crown gall disease such as gall formation, disease severity and its effect on plant characters. So, studying these factors may help for effective control of the pathogen. Matveeva et al., (2004) proposed that increasing the cytokinin / auxin ratio may lead to tumor formation on roots. Also, the development of plant tumors caused by Agrobacterium tumefaciens depends on the excessive production and synthesis of auxin (indole acetic acid) and cytokinin's by enzymes encoded on T-DNA genes integrated into the plant genome (Veselov et al., 2003 and Liu and Nester, 2006).

On the other hand, the infection of A. tumefaciens was done when the bacteria attachment to the plant cells in the wound sites. So, avirulent A. tumefaciens bacteria failed to attach at wound sites of plants, as recorded by (Matthysse and McMahan, 2001, Tan et al., 2005 and Li et al. 2008). Brencic et al. (2004 and 2005) who found that plant tumorigenesis by A. tumefaciens requires expression of the vir regulon in response to chemical signals that are thought to be released from plant wound sites.

With respect of the effect of manuring and fertilization on crown gall, Florenzano (1946) reported that nitrogen $(\mathrm{N})$ fertilization increased disease severity while phosphorus $(\mathrm{P})$ fertilization either alone or in combination with $(\mathrm{N})$ reduced the number of galls. In 1975, Abd-El-Hafez et al., found that $(\mathrm{N})$ fertilization either alone or in combination with potassium $(\mathrm{K})$ increased the severity of crown gall disease while $(\mathrm{P})$ fertilization either alone or in combination with $(\mathrm{N})$ showed considerable reduction in the number of galls. No difference between potassium treatment and the control in number of gall formation. Organic manuring treatment was found to give slightly higher number of galls per plant. Also, infected plants showed lower fresh and dry weight than healthy plants under all manuring treatments while the weight of root system was higher in diseased plants. The plant uptake of $\mathrm{N}, \mathrm{P}$ and $\mathrm{K}$ was considerably lower in infected plants than healthy ones. The recent research use some microbial preparation or biopreparations such as Rhizoagrin containing (Agrobacterium radiobacter), Flavobacterin (Flavobacterium sp.) and Rhizoenterin (Enterobacter aerogenes) Pasynkov (2002), Zavalin et al., (2003) and Gabibov (2006) as a source of fertilizers ( $N$ and P) and decreased the use of chemical compounds.

The aim of this study to know how some factors could (such as, wounding, growth regulators and fertilizers) effect on the development of crown gall disease on plants and this information may help to effect on these factors by some way due to decrease the development and severity of the disease (this way may be benefit to use in control the crown gall disease).

\section{Materials and Methods}

Preparation of Agrobacterium tumefaciens inoculum:

A suspension of A. tumefaciens isolate was prepared by inoculation of isolate No. Pp4 previously isolated from peach (previously identified by the authors Barakat et al., 2009) in nutrient glucose broth (NGB) medium and incubated for 48 Egypt. J. Phytopathol., Vol. 39, No. 1 (2011) 
hrs at $28^{\circ} \mathrm{C}$. The concentration of viable cells in the preparation was approximately adjusted to be $10^{8} \mathrm{CFU} / \mathrm{ml}$. Prepared suspension was used for inoculation in all experiments.

\section{1- Effect of wounding:}

Plants of castor-bean in pots $20 \mathrm{~cm}$ diam. (cv. Ahmar Malawi - 2-month-old) was used. Four replicates for each treatment were used and all plants were wounded by using tooth spikes (marking the depth by a ruler) in the crown region. The plants were divided into three groups depending on wound depth as follows: 1,3 or $5 \mathrm{~mm}$. Then, A. tumefaciens suspension was used to infest the soil at 3 different periods, after directly wounding plants (zero time), after $48 \mathrm{hrs}$. and $72 \mathrm{hrs}$. from wounding.

The results were recorded (by measured gall index, number and weight of galls, fresh and dry weight of root) after 45 days from the first inoculation (zero time) to the wounded plants. Whereas gall index (GI) as follows Abd-El- Aziz (2004):

$$
\mathrm{GI}=\frac{\text { Average diameter of gall }}{\text { Average diameter of stem }} \times 100
$$

- Diameter of gall = diameter of stem with gall-diameter of stem only

Data in all expermints were subjected to statistical analysis using the completely randomized block design according to Snedecor and Cochran (1980). The means of treatment in this experiment were compared using the least significant difference (L.S.D).

\section{- Design of the other experiments:}

Apricot seedlings (Baladi cv., 4 months old) were used, and these plants were planted in pots ( $20 \mathrm{~cm}$ diam.- having $2 \mathrm{~kg}$ loamy soil). Four replicates were used for each treatment and all plants were wounded by using scalpel in the crown region.

\section{2- Growth regulators production:}

A. tumefaciens suspension isolate No. Ac1 previously isolated from almond $\left(10^{8}\right.$ $\mathrm{cfu} / \mathrm{ml}$.) was added into the soil $(50 \mathrm{ml} / \mathrm{pot})$ having wounded plants. The growth regulators (indole acetic acid, gibberellic acid, abscisic acid and cytokinins) were determined and recorded in plants after 7, 15, 30 and 45 days from inoculation, respectively.

Also, suspension of different A. tumefaciens isolates from almond, peach, and rosella plants (these isolates previously identified by the authors Barakat et al., 2009) were prepared in NGB medium and then the suspension of each isolates of $A$. tumefaciens was added into the soil at the rate of $50 \mathrm{ml} /$ pot. The growth regulators were determined and estimation in plants after 48 days from inoculation (gall index of each infected plants were measured and recorded before estimation of growth regulators). In control, for growth regulators experiment plants wounded only without $A$. tumefaciens inoculation. 
Measured of the hormones was carried out in Faculty of Agriculture Research Park (FARP), Cairo University. Then measured the ratio between the three plant hormones (Indole acetic acid, gibberellic acid and cytokinins)

Indole acetic acid, gibberellic acid, abscisic acid and cytokinins were extracted according to Prakash and Prathapasenan (1990). Two- gram samples of apricot root plants were homogenized in a mixture of methanol: chloroform $(14: 6 \mathrm{v} / \mathrm{v})$ and maintained for one week at $-20^{\circ} \mathrm{C}$. The extracts were then filtered through a Whatman No. 5 filter paper and the residue was adjusted to $\mathrm{pH} 8.5$ with $1 \mathrm{~N} \mathrm{NaOH}$ and transferred through a separating funnel to separate chloroform from methanol. The chloroform phase was discarded. The methanol phase was reduced to the aqueous phase in a rotary evaporator at $40^{\circ} \mathrm{C}$. The aqueous phase was then adjusted to $\mathrm{pH} 2.5$ with $1 \mathrm{NHCl}$ and partitioned 3 times against ethyl acetate to take acidic free hormones and dried under vacuum at $40^{\circ} \mathrm{C}$. The residue was dissolved in one $\mathrm{ml}$ of absolute methanol and transferred into an Eppendorf tube. The methanol was reduced to $100 \mu 1$.

A method for the simultaneous separation and determination of plant internal hormones in plants by gas chromatography with wide - pore capillary column was employed. The gas chromatographic conditions were as follows: FID detector; TR $5 \mathrm{MS}$ capillary column, $30 \mathrm{~m} \times 0.25 \mathrm{~mm} \times 0.25$ microns film. The injection temperature was, $270^{\circ} \mathrm{C}$; the detector temperature, $270^{\circ} \mathrm{C}$, carrier gas, $30 \mathrm{ml} / \mathrm{min} \mathrm{N}_{2}$. All components were separated in $20 \mathrm{~min}$.

\section{3- Effect of fertilizers:}

The effects of nitrogen, phosphorus, and potassium fertilizers either alone or in combinations, together with organic manuring on the gall index as well as fresh and dry weight of apricot plants (Baladi cv., 4 months old) were studied. The suspension of A. tumefaciens isolate No. Pp4 $(50 \mathrm{ml} / \mathrm{pot})$ was added into the pots $(20 \mathrm{~cm}$ diam.having $2 \mathrm{~kg}$ loamy soil) containing the wounded plants.

Fertilizer treatments were applied by using ammonium nitrate $(33 \% \mathrm{~N})$, calcium super phosphate $(15 \% \mathrm{P})$ and potassium sulphate $(50 \% \mathrm{~K})$. These compounds were dissolved in water and used at the rate of $15,33.3$ and $10 \mathrm{~g} / 1$, respectivily to have concentration of $0.5 \%$ (this designer of requirements as recommended by Deciduous Fruits Department, Horticultural Research Institute, ARC. and according to Murat et al., (2007).

Compost (Turned) produced from a mixture of animal manure and rice straw by ECARU Company was provided and analysis (Table 1) by Microbiology Department, Soil, Water and Environment Research Institute, ARC. and was applied at the rate of $50 \mathrm{~g} /$ pot.

Fertilizer treatments were applied as single (N, P, K, and compost) or as combinations (NP, NK, PK, NPK and NPK plus compost). After inoculation, the soil with A. tumefaciens, fertilizers $(50 \mathrm{ml} / \mathrm{pot})$ were added to the soil. Fertilizers were added to pots weekly for 42 days which equals $300 \mathrm{ml} /$ pot for each treatment through the experiment. In control treatment soil was inoculated with A. tumefaciens

Egypt. J. Phytopathol., Vol. 39, No. 1 (2011) 
without fertilization. Disease readings were recorded after 45 days from inoculation by measured gall index, number of galls, fresh and dry weight of gall, fresh and dry weight of shoot and root and the height of plant.

Table (1): Physical and chemical analysis of compost.

\begin{tabular}{l|c}
\multicolumn{1}{c|}{$\begin{array}{c}\text { Characters } \\
\text { Weight of } \mathrm{m}^{3} \mathrm{Kg}\end{array}$} & Compost \\
& 745 \\
\hline Humidity \% & 14 \\
$\mathrm{pH}(1: 10)$ & 7.99 \\
$\mathrm{EC}(1: 10)\left(\mathrm{mm} \mathrm{cm}^{-1}\right)$ & 3.54 \\
Ammonium nitrogen ppm & 706 \\
Nitrate nitrogen ppm & 54 \\
Total nitrogen \% & 0.98 \\
Organic material \% & 24.57 \\
Organic carbon \% & 14.25 \\
C / N ratio & $14.54: 1$ \\
Total phosphorus \% & 0.74 \\
Total potassium \% & 0.35 \\
\hline
\end{tabular}

- Mineral content of treated plants:

Determination of total nitrogen, phosphorus and potassium were measured as adopted by Faculty of Agriculture Research Park

(FARP), Cairo University.

Plants were separated into galls, shoots and roots, and all tissues of the plant were immediately weighted. Then, separately plant was cut into small pieces and dried at $70^{\circ} \mathrm{C}$ for $24 \mathrm{hrs}$. in hot air oven. The samples of plants were ground into powder and used for determination of total nitrogen, phosphorus and potassium.

\section{-Determination of total nitrogen:}

Total nitrogen was determined by the usual Kjeldahl method as follows: The dried samples were digested with concentrated sulfuric acid in the presence of digestion catalysts (a mixture of copper sulfate and anhydrous sodium sulfate, 1:10). Then total nitrogen was determined titrimetric according to AOAC (1995).

\section{-Determination of total phosphorus:}

The phosphate ion reacts with molybdate to produce phospho-molybdate, which is finally reduced to a molybdenum blue. This compound was determined colorimetrically according to El-Merzabani et al. (1977) by using T80 uv/vis spectrometer from PG instruments LTd company with $650 \mathrm{~nm}$ wavelength.

-Determination of total potassium:

This method provides for the acid digestion of the sample in a closed vessel device using temperature control microwave heating $\left(180^{\circ} \mathrm{C}\right)$ for the metal determination by spectroscopic methods. The dried samples were digested in nitric acid by using Advanced Microwave digestion system ETHOS1 produced by 
Microwave equipment, Milestone ETHOS lab station, USA. The reagents were $7 \mathrm{ml}$ of $\mathrm{HNO}_{3} 65 \%, 2 \mathrm{ml}$ of $\mathrm{H}_{2} \mathrm{O}_{2} 30 \%$. Then, measured on Thermo Scientific iCAP 6000 Series of ICP emission spectrometer.

\section{Statistical analysis:}

The collected data were analyzed using ANOVA statistical analysis (Snedecor and Cochran, 1980). The least significant difference (L.S.D) was used to compare between the means.

\section{Results}

\section{1- Effect of wounds, depth, and time of bacterial application:}

Data in Table (2) revealed that a fresh wound is necessary for tumor cell formation. In general, the role of wounding is played within the first few days after the initial injury. Good tumor formation was evident on plants inoculated at 0 time. Determination of gall index (GI) which can be taken as a criterion of the severity of infection indicated the highest GI in plants inoculated at 0 time being 75, 259.3 and 228 at wound depth 1,3 and $5 \mathrm{~mm}$, respectively. The lowest figure was apparent following the 48 and $72 \mathrm{hrs}$. application of bacteria. All treatments and their statistically significant at 0.05 LSD.

Table (2): Effect of wounds on the incidence of gall development (GI) on castor bean plants.

\begin{tabular}{|c|c|c|c|c|}
\hline \multirow{2}{*}{$\underbrace{\text { Depth }}_{\text {Time }}$} & \multicolumn{4}{|c|}{ Gall index \% } \\
\hline & $1 \mathrm{~mm}$ & $3 \mathrm{~mm}$ & $5 \mathrm{~mm}$ & Mean \\
\hline 0 time & 75.0 & 259.3 & 228.0 & 187.4 \\
\hline $48 \mathrm{hrs}$. & 50.0 & 88.3 & 136.6 & 91.6 \\
\hline $72 \mathrm{hrs}$. & 80.0 & 80.0 & 150.0 & 103.3 \\
\hline Mean & 68.3 & 142.5 & 171.5 & 128.8 \\
\hline \multicolumn{5}{|l|}{ LSD at 0.05} \\
\hline Depth & \multicolumn{4}{|c|}{43.11} \\
\hline Time & \multicolumn{4}{|c|}{86.22} \\
\hline Depth $\times$ Time & \multicolumn{4}{|c|}{49.78} \\
\hline
\end{tabular}

It is clear from the same table that not only the time of bacterial application effect on GI but also the injured cells expressed with different wound depths are the second factor on gall development. In this respect the size of the tumor is usually directly proportional to the severity of the wound (wound depth). It showed that the higher GI at wound depth $5 \mathrm{~mm}$ and the lowest one at $1 \mathrm{~mm}$. This was statistically significant at LSD 0.05 .

Data in Table (3) indicate that the eventual size of a tumor is independent on the number of bacteria in the inoculum used but the larger amount of wound sap present in massive wounds were related to the size of tumors which reflecting on the number of galls. It was obvious from these data that a significant difference among simultaneous inoculation with one $\mathrm{mm}$ wounds and the other deeper wounds (i.e., 3

Egypt. J. Phytopathol., Vol. 39, No. 1 (2011) 
$\mathrm{mm}$ and $5 \mathrm{~mm}$ ). No difference between $48 \mathrm{hrs}$. and $72 \mathrm{hrs}$. time of inoculation at all depth. This indicates that the wound sap produced or released from fresh and deep wounds have a significant important role in gall formation.

Table (3): Effect of wounds on the incidence of galls number on castor bean plants.

\begin{tabular}{|c|c|c|c|c|}
\hline \multirow{2}{*}{ Dime } & \multicolumn{4}{|c|}{ Av. No. of galls / plants } \\
\hline & $1 \mathrm{~mm}$ & $3 \mathrm{~mm}$ & $5 \mathrm{~mm}$ & Mean \\
\hline 0 time & 1.50 & 3.67 & 2.00 & 2.39 \\
\hline $48 \mathrm{hrs}$. & 1.00 & 1.00 & 1.30 & 1.10 \\
\hline $72 \mathrm{hrs}$. & 1.00 & 1.00 & 1.30 & 1.10 \\
\hline Mean & 1.16 & 1.90 & 1.53 & 1.50 \\
\hline \multicolumn{5}{|l|}{ LSD at 0.05} \\
\hline Depth & \multicolumn{4}{|c|}{ NS } \\
\hline Time & \multicolumn{4}{|c|}{ NS } \\
\hline Depth $\times$ Time & \multicolumn{4}{|c|}{0.64} \\
\hline
\end{tabular}

NS: denotes non- significant

Data in Table (4) showed the fresh weight of galls which reflect on the number of gall formation. Data indicated that no significant differences at wound depth 1 and $5 \mathrm{~mm}$ at 48 and $72 \mathrm{hrs}$. but there are significant differences at depth $3 \mathrm{~mm}$ between 0 time which was $0.97 \mathrm{~g}$ and other time of inoculation 0.14 and 0.13 for 48 and 72 hrs., respectively.

Table (4): Effect of wounds, its depth and time of inoculation on the weight of galls developed on castor bean plants.

\begin{tabular}{lcccc}
\hline & \multicolumn{4}{c}{ Av. No. of galls / plants } \\
\cline { 2 - 5 } \multicolumn{1}{c}{ Time } & \multirow{2}{*}{ Depth } & $3 \mathrm{~mm}$ & $5 \mathrm{~mm}$ & Mean \\
\hline 0 time & 0.08 & 0.97 & 0.52 & 0.52 \\
$78 \mathrm{hrs}$. & 0.05 & 0.14 & 0.53 & 0.24 \\
Mean & 0.10 & 0.13 & 0.17 & 0.13 \\
\hline LSD at 0.05 & 0.07 & 0.40 & 0.40 & 0.29 \\
$\quad$ Depth & \multicolumn{3}{c}{0.20} \\
$\quad$ Time & \multicolumn{3}{c}{0.41} \\
Depth $\times$ Time & \multicolumn{3}{c}{0.24} \\
\hline
\end{tabular}

It is clear from Tables (5) that no significant differences showed among all wound depths with different inoculation time. On the other hand, results of fresh weight of roots showed a significant difference in $3 \mathrm{~mm}$ wound depth in inoculation time $72 \mathrm{hrs}$. compared with the other times of inoculation ( 0 time and $48 \mathrm{hrs}$ ), as well as the same at $5 \mathrm{~mm}$ depth after $72 \mathrm{hrs}$. from wounded plants. With respect of dry weight of root, the same figure was observed. 
Table (5): Effect of wound depth and time of inoculation on the roots fresh and dry weight of castor bean plants.

\begin{tabular}{|c|c|c|c|c|c|c|c|c|}
\hline \multirow{3}{*}{ Depth } & \multicolumn{8}{|c|}{ Av. Wt. of fresh and dry roots / plants (g) } \\
\hline & \multicolumn{2}{|c|}{$1 \mathrm{~mm}$} & \multicolumn{2}{|c|}{$3 \mathrm{~mm}$} & \multicolumn{2}{|c|}{$5 \mathrm{~mm}$} & \multicolumn{2}{|c|}{ Mean } \\
\hline & Fresh & Dry & Fresh & Dry & Fresh & Dry & Fresh & Dry \\
\hline 0 time & 9.95 & 2.17 & 4.19 & 1.37 & 7.45 & 1.74 & 7.20 & 1.76 \\
\hline 48 hrs. & 4.81 & 1.19 & 7.72 & 2.10 & 6.84 & 1.57 & 6.46 & 1.62 \\
\hline 72 hrs. & 6.74 & 1.54 & 13.61 & 3.22 & 2.79 & 0.69 & 7.71 & 1.82 \\
\hline Mean & 7.17 & 1.63 & 8.51 & 2.23 & 5.69 & 1.33 & 7.12 & 1.73 \\
\hline LSD 0.05 & \multicolumn{4}{|c|}{ For fresh wt. } & \multicolumn{4}{|c|}{ For dry wt. } \\
\hline Depth & \multicolumn{4}{|c|}{ NS } & \multicolumn{4}{|c|}{ NS } \\
\hline Time & \multicolumn{4}{|c|}{5.71} & \multicolumn{4}{|c|}{1.14} \\
\hline Depth x Time & \multicolumn{4}{|c|}{ NS } & \multicolumn{4}{|c|}{ NS } \\
\hline
\end{tabular}

NS: denotes non- significant

\section{2- Growth regulators production}

Data in Table (6) indicate that different isolates of A. tumefaciens isolated from different hosts could produce different rates of growth regulators in infected apricot plants. Almond isolate which causes a high root gall index (i. e. GI 200) produced the highest rates of indole acetic acid (IAA) $1.69 \mu \mathrm{g} / 100 \mathrm{~g}$ fresh root weight (FW) followed by the rosella isolate having GI of 125 which produced $0.97 \mu \mathrm{g} / 100 \mathrm{~g}$ FW. However, the more aggressive isolate of peach (Pp4) having GI of 250 produced $0.084 \mu \mathrm{g} / 100 \mathrm{~g}$ FW. Whereas, gibberellic acid (GA3) production was different compared with IAA, the lowest rate from almond isolate $(0.39 \mu \mathrm{g} / 100 \mathrm{~g}$ FW) then rosella isolate $(1.88 \mu \mathrm{g} / 100 \mathrm{~g} \mathrm{FW})$ and the highest rate production from peach isolate $(2.39 \mu \mathrm{g} / 100 \mathrm{~g} \mathrm{FW})$.

Table (6): Effect of different Agrobacterium tumefaciens isolates on growth regulators production $(\mu \mathrm{g} / 100 \mathrm{~g}$ fresh weight $\mathrm{FW})$.

\begin{tabular}{ccccccc}
\hline Substances & \multirow{2}{*}{$\begin{array}{c}\text { Source } \\
\text { of }\end{array}$} & $\begin{array}{c}\text { Gall } \\
\text { index }\end{array}$ & & \multicolumn{4}{c}{$\begin{array}{c}\text { Growth regulators / plants } \\
(\mu \mathrm{g} / 100 \mathrm{~g} \mathrm{~F} \text {.W })\end{array}$} \\
\cline { 5 - 7 } isolates & isolates & IAA & GA3 & ABA & CK \\
\hline Ac1 & Almond & 200 & 1.690 & 0.39 & 0.015 & 871.33 \\
Pp4 & Peach & 250 & 0.084 & 2.39 & 0.059 & 1431.65 \\
Hs19 & Rosella & 125 & 0.970 & 1.88 & 0.068 & 579.68 \\
\cline { 3 - 7 } Control & $\mathrm{N}$ & 0 & 4.77 & 2.74 & 0.07 & 494.37 \\
\hline
\end{tabular}

IAA = Indole acetic acid; GA3 = Gibberellic acid; $\mathrm{ABA}=$ Abscisic acid $\mathrm{CK}=$ Cytokinin; $\mathrm{N}=$ Non infected plants

Production of abscisic acid (ABA) was highest by rosella isolate $(0.068 \mu \mathrm{g} / 100 \mathrm{~g}$ FW) followed by peach isolate $(0.059 \mu \mathrm{g} / 100 \mathrm{~g} F W)$ and the lowest one was produced by almond isolate $(0.015 \mu \mathrm{g} / 100 \mathrm{~g} \mathrm{FW})$. But production rate of cytokinin

Egypt. J. Phytopathol., Vol. 39, No. 1 (2011) 
(CK) have a variation according to the isolates aggressiveness on apricot plants whereas, peach isolate (has the highest GI) showed the highest rate of cytokinin's production $(1431.65 \mu \mathrm{g} / 100 \mathrm{~g} \mathrm{FW})$ followed by almond isolate in which cytokinin was $871.33 \mu \mathrm{g} / 100 \mathrm{~g} \mathrm{FW}$ and the last one was rosella isolate which produced the lowest rate of cytokinin $(579.68 \mu \mathrm{g} / 100 \mathrm{~g} \mathrm{FW})$.

Data in Table (7) indicate that the production and ratio of IAA, GA3 and CK were affected the crown gall disease development. Although, the highest GI produced from peach isolate $(\mathrm{Pp} 4)$, this isolate has the highest CK / IAA and CK / IAA with GA3 ratio but moderate in CK / GA3 ratio. Isolate (Ac1) from almond have moderate GI have the lowest $\mathrm{CK} / \mathrm{IAA}$ ratio, highest CK / GA3 ratio and moderate CK / IAA with GA3 ratio. The lowest GI produce by rosella isolate (Hs19) which have moderate CK / IAA ratio and the lowest CK / GA3 and CK / IAA with GA3 ratio.

Also, Table (7) prove that the highest correlation between the isolate's aggressiveness and the growth regulators production ratio was recorded between CK / IAA with GA3 ratio which was 0.97 , followed by CK / GA3 ratio (0.88) and the last and lowest one was CK / IAA ratio (0.67).

Data indicate that also production of GA3 was necessary to crown gall disease development. So, gall formation development dependent the production of the three plant hormones together (IAA, GA3 and CK) and the ratio between CK / IAA with GA3, not depended on the production of IAA and CK as well as the ratio between them. Whereas the highly aggressiveness isolate have the highest CK / IAA with GA3 ratio and the lowest isolate in aggressive produced the lowest CK / IAA with GA3 ratio.

Table (7): Differentiation between growth regulators ratio in apricot plants infected with different isolates of Agrobacterium tumefaciens.

\begin{tabular}{lcccc}
\hline \multicolumn{1}{c}{ Isolates } & GI & CK /IAA ratio & $\begin{array}{c}\text { CK / GA3 } \\
\text { ratio }\end{array}$ & $\begin{array}{c}\text { CK / IAA + } \\
\text { GA3 ratio }\end{array}$ \\
\hline Ac1 & 200 & $515.58: 1$ & $739.20: 1$ & $418.91: 1$ \\
Pp4 & 250 & $17043.35: 1$ & $599.02: 1$ & $578.68: 1$ \\
Hs19 & 125 & $596.91: 1$ & $308.34: 1$ & $203.40: 1$ \\
\cline { 2 - 5 } Control & 0 & $103.64: 1$ & $180.43: 1$ & $65.83: 1$ \\
\hline Correlation (r) & - & 0.67 & 0.88 & 0.97 \\
\hline
\end{tabular}

IAA = Indole acetic acid; GA3 = Gibberellic acid; ABA = Abscisic acid; $\mathrm{CK}=$ Cytokinin; Control $=$ Non infected plants

Data in Table (8) and Figs. (1, 2 and 3) showed that production of growth regulators was different according to development of gall formation. Whereas production of IAA was decreased in plants infected with A. tumefaciens from 0.84 
$\mu \mathrm{g} / 100 \mathrm{~g}$ FW to $0.48 \mu \mathrm{g} / 100 \mathrm{~g}$ FW after 15 days from inoculation compared with the control. At the same time, it was increased from 0.91 to $1.59 \mu \mathrm{g} / 100 \mathrm{~g} \mathrm{FW}$, then IAA was increased again in the infected plants to $0.83 \mu \mathrm{g} / 100 \mathrm{~g}$ FW after 30 days from inoculation and increased again in the last stage of gall formation after 45 days from inoculation to $1.69 \mu \mathrm{g} / 100 \mathrm{~g}$ FW compared with the control. After 30 and 45 days IAA increased to 1.82 and $4.77 \mu \mathrm{g} / 100 \mathrm{~g}$ FW, respectively.

Also, production of gibberellic acid (GA3) was decreased in infected plants from $17.30 \mu \mathrm{g} / 100 \mathrm{~g}$ FW to $10.58 \mu \mathrm{g} / 100 \mathrm{~g}$ FW after 15 days from inoculation but in control the production of GA3 was increased from 2.57 to 7.06 at the same time. Production of GA3 in the roots of infected plants was increased again to $10.75 \mu \mathrm{g}$ /100g FW after 30 days from inoculation then decreased in the last stage of gall formation reaching to $0.39 \mu \mathrm{g} / 100 \mathrm{~g} \mathrm{FW}$ after 45 days from inoculation. In noninfected plants, GA3 increased to $29.84 \mu \mathrm{g} / 100 \mathrm{~g}$ FW and then decreased to $2.74 \mu \mathrm{g}$ $/ 100 \mathrm{~g}$ FW at the same time.

But, the production of abscisic acid (ABA) showed different trend as it increased from $0.75 \mu \mathrm{g} / 100 \mathrm{~g} \mathrm{FW}$ to $1.03 \mu \mathrm{g} / 100 \mathrm{~g}$ FW after 15 days from inoculation and then sharply decreased more at the last stage of gall formation to $0.015 \mu \mathrm{g} / 100 \mathrm{~g}$ FW. In control check plants (ABA) was increased from 0.15 to $0.29 \mu \mathrm{g} / 100 \mathrm{~g}$ FW and increased to $1.83 \mu \mathrm{g} / 100 \mathrm{~g} \mathrm{FW}$ then decreased to $0.07 \mu \mathrm{g} / 100 \mathrm{~g}$ FW at the respective periods.

On the other hand, initial cytokinins (CK) content of apricot plants was decreased after inoculation within 15 days to reach $24.65 \mathrm{mg} / 100 \mathrm{~g} \mathrm{FW}$, then increased to $42,82 \mathrm{mg} / 100 \mathrm{~g} \mathrm{FW}$ after 30 days and at the last stage of gall formation after 45 days it remarkably increased to reach $871.33 \mathrm{mg} / 100 \mathrm{~g}$ FW compared with $494.37 \mu \mathrm{g} / \mathrm{g} \mathrm{FW}$ in control check plants at the same time. So, production of cytokinins in the infected plants by A. tumefaciens in all stage of gall formation showed an increment compared with the control plants.

Table (8): Differentiation of growth regulators production in different stages of gall formation by Agrobacterium tumefaciens (Ac1 isolate) in apricot roots.

\begin{tabular}{lccccccccc}
\hline & & \multicolumn{9}{c}{ Growth regulators amount $(\mu \mathrm{g} / 00 \mathrm{~g}$ root fresh weight $)$} \\
\cline { 3 - 10 } Stages & GI & \multicolumn{2}{c}{ IAA } & \multicolumn{2}{c}{ GA3 } & \multicolumn{2}{c}{ ABA } & \multicolumn{3}{c}{ CK } \\
\cline { 3 - 10 } & & Ac1 & $(\mathrm{C})$ & Ac1 & $(\mathrm{C})$ & Ac1 & $(\mathrm{C})$ & Ac1 & $(\mathrm{C})$ \\
\hline 7 days & 0 & 0.84 & 0.91 & 17.30 & 2.57 & 0.750 & 0.15 & 52.83 & 10.85 \\
15 days & 44 & 0.48 & 1.59 & 10.58 & 7.06 & 1.030 & 0.29 & 24.65 & 9.36 \\
30 days & 107 & 0.83 & 1.82 & 10.75 & 29.84 & 0.290 & 1.83 & 42.82 & 2.85 \\
45 days & 200 & 1.69 & 4.77 & 0.39 & 2.74 & 0.015 & 0.07 & 871.33 & 494.37 \\
\hline
\end{tabular}

(C): Control non infected plants

Egypt. J. Phytopathol., Vol. 39, No. 1 (2011) 


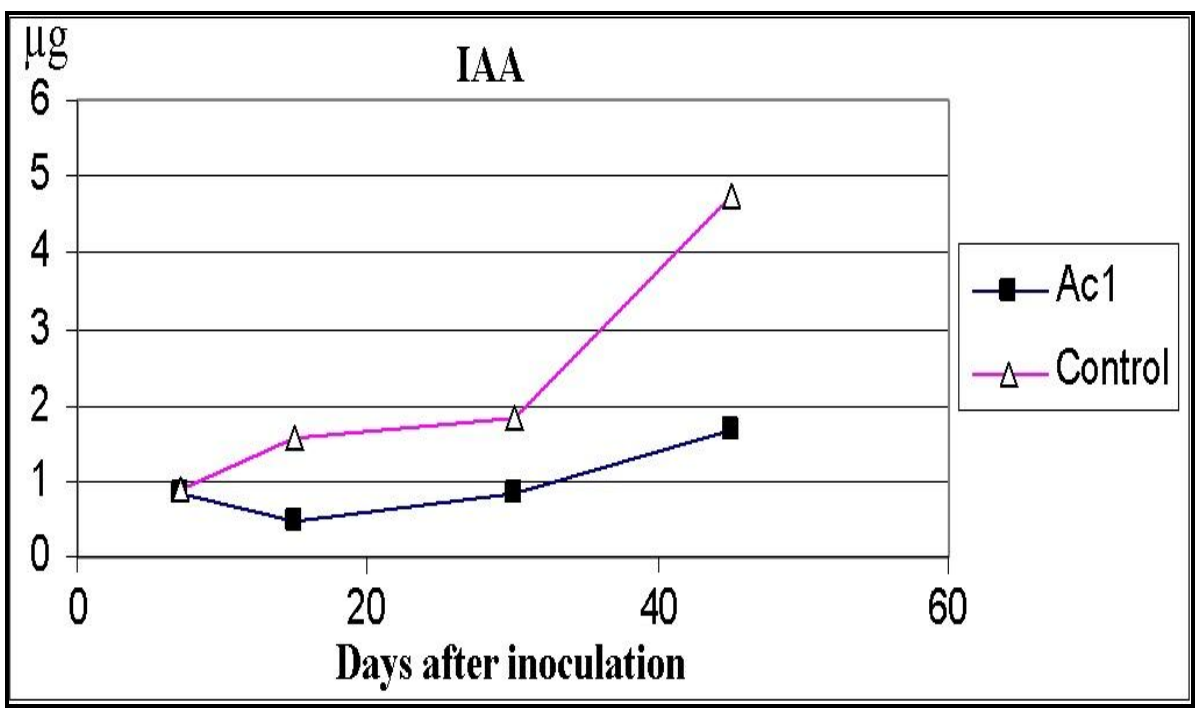

Fig. (1): Differentiation of production of IAA growth regulators $(\mu \mathrm{g} / 100 \mathrm{~g}$ fresh weight FW) in different stages of gall formation by Agrobacterium tumefaciens in apricot roots. Ac1: Almond isolate Control: Non infected plants

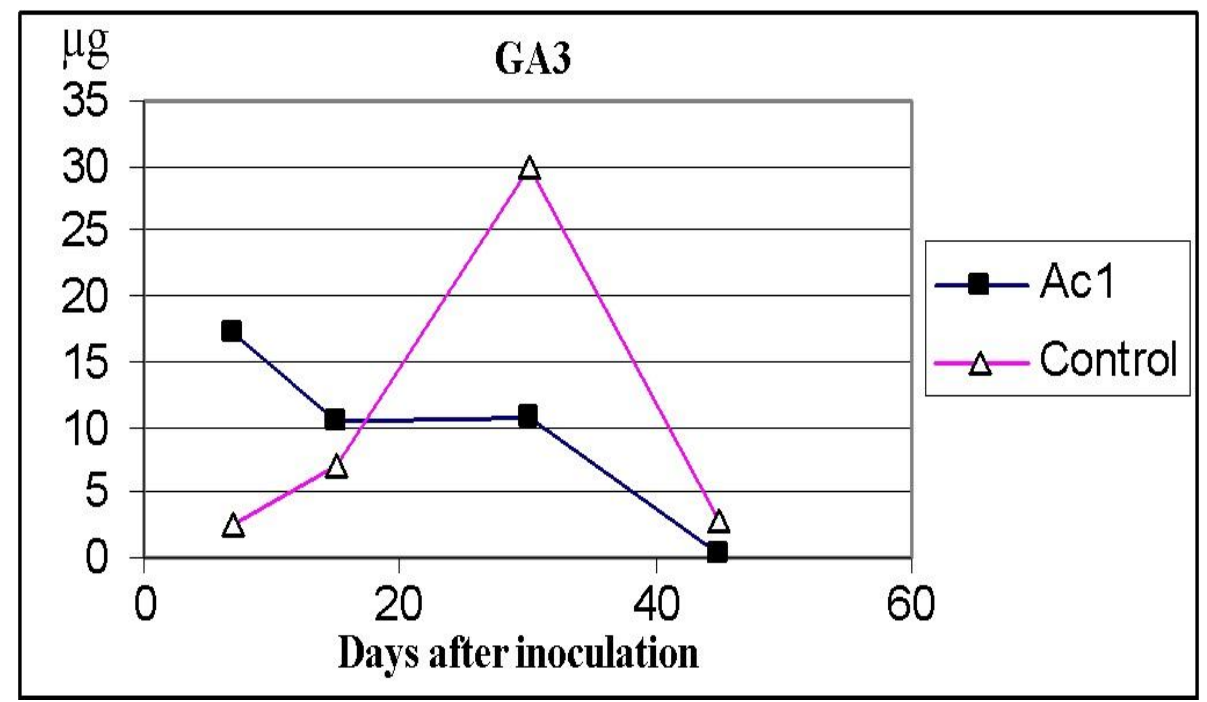

Fig. (2): Differentiation of production of GA3 growth regulators $(\mu \mathrm{g} / \mathrm{100g}$ fresh weight FW) in different stage of gall formation by Agrobacterium tumefaciens in apricot roots. (Ac1: Almond isolate; Control: Non infected plants) 


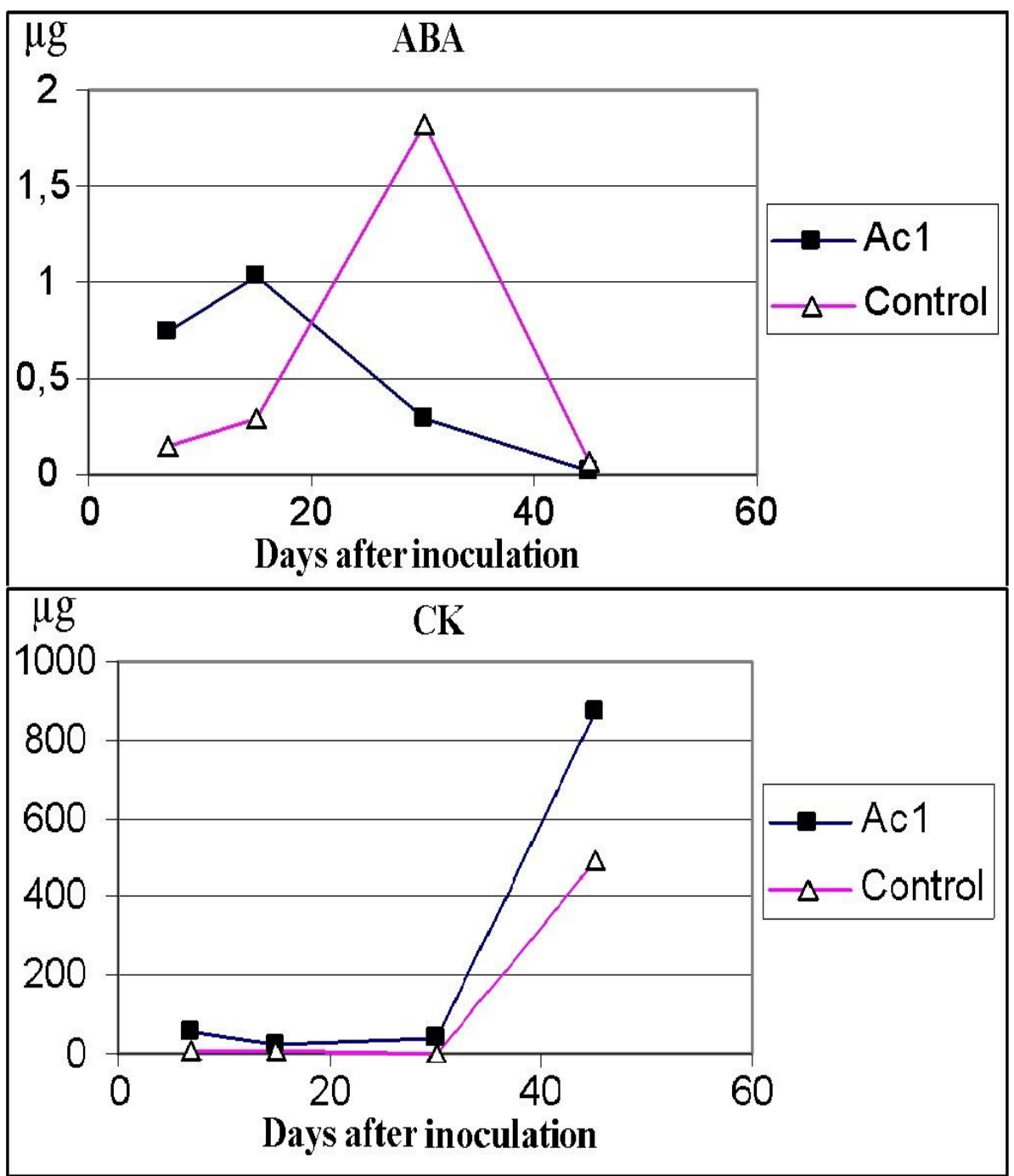

Fig. (3): Differentiation of production of $\mathrm{ABA}$ and CK growth regulators ( $\mu \mathrm{g}$ / $100 \mathrm{~g}$ fresh weight FW) in different stage of gall formation by $A$. tumefaciens in apricot roots. (Ac1: Almond isolate; Control: Non infected plants)

a- Effect of fertilization on gall formation

It is clear from Table (9) that the average number of galls was 3.5 /plant in the control treatment. Phosphorus and potassium fertilization either alone or in combination with nitrogen resulted is a considerable reduction in the average number of galls reaching 1.7, 1.3, 1.3, 1.0 and 1.0 for P, K, NP, PK and NPK treatments, respectively. 
Although nitrogen fertilizer alone or in combination with compost (produced from a mixture of animal manure and rice straw) was found increase of average of gall formation than the other treatment of NP and NK. It seems that the presence of two fertilizers in combination resulted in balanced absorption of two elements. Such conditions might give the growing plants higher resistance to the disease.

Table (9): Effect of fertilization on number of galls, gall index and the weight of galls caused by crown gall disease on apricot.

\begin{tabular}{lcccc}
\hline \multirow{2}{*}{ Treatments } & $\begin{array}{c}\text { Av. No. of } \\
\text { galls / plant }\end{array}$ & $\begin{array}{c}\text { Gall index } \\
(\mathrm{GI})\end{array}$ & \multicolumn{2}{c}{ Av. wt. of galls / plant $(\mathrm{g})$} \\
\cline { 5 - 5 } $\mathrm{N}$ & 2.0 & 158.8 & 0.33 & 0.10 \\
$\mathrm{P}$ & 1.7 & 183.3 & 0.10 & 0.04 \\
$\mathrm{~K}$ & 1.3 & 124.8 & 0.18 & 0.06 \\
$\mathrm{NP}$ & 1.0 & 99.8 & 0.10 & 0.04 \\
$\mathrm{NK}$ & 1.0 & 112.3 & 0.19 & 0.09 \\
$\mathrm{PK}$ & 1.3 & 191.5 & 0.14 & 0.08 \\
$\mathrm{NPK}$ & 1.0 & 87.3 & 0.22 & 0.09 \\
Compost $(\mathrm{C})$ & 2.0 & 174.5 & 0.11 & 0.03 \\
NPK+ (C) & 1.8 & 143.8 & 0.39 & 0.10 \\
Control & 3.5 & 191.3 & 0.18 & 0.07 \\
\hline LSD\% at 0.05 & $\mathrm{NS}$ & 1.1 & $\mathrm{NS}$ & NS \\
\hline
\end{tabular}

With respect to the fresh and dry weight of galls, it was found that although control treatment showed higher incidence of galls than other treatments alone or in combination, it showed lower fresh and dry weight of galls. This indicates that galls formed on the control treatment were smaller in size. The highest fresh and dry weights of galls, however, observed in N alone and NPK and NPK plus manure reaching $0.33,0.22$ and $0.39 \mathrm{~g} /$ plant. The lowest figure was observed in $\mathrm{P}$ and $\mathrm{K}$ alone or in combination (PK) and in combination with nitrogen (NP) and (NK).

It is clear from Table (10) that manuring treatments showed significant differences than the control. Nitrogen application in combination with phosphorus slightly decreased fresh and dry weights, while both NPK and compost treatments resulted in considerably increase in plant weight over the other treatments. It was found from the same Table that there is clear relation between the plant height and the vegetative growth of apricot plants. This might be a reflection of the effect of the disease of plant growth especially in applications of (N), (NP) and compost treatments whereas the plant height reaching $39.7,34.5$ and $36.7 \mathrm{~cm}$, respectively. 
Table (10): Effect of fertilization on fresh and dry weight of shoot, roots, and height of apricot plants

\begin{tabular}{cccccc}
\hline \multirow{2}{*}{ Treatments } & \multicolumn{2}{c}{$\begin{array}{c}\text { Av. wt. of shoot / } \\
\text { plant (g) }\end{array}$} & \multicolumn{2}{c}{ Av. wt. of root / plant (g) } & $\begin{array}{c}\text { Av. Height } \\
\text { of plant } \\
\end{array}$ \\
\cline { 2 - 5 } (cm)
\end{tabular}

Data in Table (11) showed that nitrogen percentage of the control was considerably lower than other treatments. It seems that total nitrogen per plant could be taken as a good criterion for plant uptake rather than determining its percentage. Thus, it is clear that total nitrogen percent was high in treatment receiving N, NPK and NPK plus compost. Total $\mathrm{N}$ per $100 \mathrm{~g}$ plant reached 3.9, 2.8 and 3.0g for these treatments, respectively. The same figure was also observed for $\mathrm{K}$ and $\mathrm{P}$ treatments. The lowest $\mathrm{N}$ uptake was observed in NP treatment.

With respect to plant uptake of phosphorus as indicated by total phosphorus per plant it is clear that the uptake was similar between all application treatments and the control. It was found from such data that NPK treatment and inoculation influenced with $\mathrm{K}$ content of plants. Total $\mathrm{K}$ uptake was higher compared with other treatments, this highest uptake in NPK treatment which indeed showed a low disease severity as indicated by gall index (GI).

Table (11). Effect of fertilization on mineral composition of apricot plants.

\begin{tabular}{cccc}
\hline Fertilizers & $\begin{array}{c}\text { mineral } \\
\text { nitrogen } \\
(\mathrm{g} / 100 \mathrm{~g})\end{array}$ & $\begin{array}{c}\text { content } \\
\text { phosphorus } \\
(\mathrm{g} / 100 \mathrm{~g})\end{array}$ & $\begin{array}{c}\text { / plant } \\
\text { potassium } \\
(\mathrm{mg} / 100 \mathrm{~g})\end{array}$ \\
\hline $\mathrm{N}$ & 3.967 & 0.18 & 4.456 \\
$\mathrm{P}$ & 2.661 & 0.22 & 3.673 \\
$\mathrm{~K}$ & 2.892 & 0.19 & 4.982 \\
$\mathrm{NP}$ & 1.681 & 0.28 & 4.262 \\
$\mathrm{NK}$ & 2.871 & 0.22 & 6.306 \\
$\mathrm{PK}$ & 2.295 & 0.25 & 6.111 \\
$\mathrm{NPK}$ & 2.891 & 0.26 & 6.776 \\
Compost (C) & 2.398 & 0.26 & 5.451 \\
NPK+ (C) & 3.003 & 0.28 & 4.717 \\
Control & 0.503 & 0.23 & 5.451 \\
\hline
\end{tabular}

Egypt. J. Phytopathol., Vol. 39, No. 1 (2011) 


\section{Dis c us s i on}

The purpose of this study to know how some factors could (such as, wounding, growth regulators and fertilizers) effect on the development of crown gall disease and increased or decreased its severity on plants. This information may help to effect on these factors by some way to decrease the development and severity of the disease (these ways may be benefitted to use in control the crown gall disease).

In crown gall disease wound site are necessary step in the infection to induce gall formation. The attached bacterium initiates the transfer of T- DNA under the influence of chemicals produced by wounded plant cells, it is clear that if wounds didn't find, the bacterium couldn't attach to the host cell (Tan et al., 2005 and Li et al., 2008).

Also, wounding is known to be essential for crown gall infection due to woundreleased chemicals that induce the expression of virulence genes in A. tumefaciens leading to transfer of T-DNA to the plant cell. In this respect, many investigations belong to wound sap are of considerable interest (Wise et al., 2005 and Brencic et al., 2004 and 2005).

The eventual size of tumor is independent of the number of bacteria comprising an inoculum; the size of the tumor is directly proportional to the severity of the wound. In the present study, the wound depth of 3 and $5 \mathrm{~mm}$ resulted an increase in severity of disease while less size of galls was shown at wound depth $1 \mathrm{~mm}$ due to the higher products released from deeper wounded tissues.

In addition, time of inoculation with A. tumefaciens after wounding plant was necessary for successful infection. It was proved that inoculation directly after wounding plants caused an increase in its severity and in gall formation compared with long periods after wounding $48 \mathrm{hrs}$. and $72 \mathrm{hrs}$. of inoculation in which wound healing processes started fast in superficial wounds compared with deeper. The present results agree with those obtained by Hildebrand 1942, Braun 1952 and Brencic et al., 2004 and 2005.

Growth regulators production by isolates of A. tumefaciens revealed different amounts and ratio from IAA, GA3, ABA and CK in the plants and no relationship between the production amount of IAA, GA3 and ABA individually and the aggressiveness of isolates but production amount of CK only and IAA with GA3 was increased when the isolates aggressiveness was high. Whereas the highest GI obtained from peach isolate and the highest amount and ratio of CK and IAA with GA3 produced from this isolate. While the lowest isolates in aggressive (GI 125) produced the lowest amount and ratio of CK and IAA with GA3.

So, results revealed that $A$. tumefaciens aggressiveness dependent the production amount of the three plant hormones IAA, GA3 and CK together. Since some similarity articles recorded that GA3 was tested for its effect on tumor induction by A. tumefaciens in primary pinto bean (Phaseolus vulgaris L) (Anand et al., 1975), also, ElKhalifa and Yousif (1974) recorded GA3 was found to increase secondary 
tumor initiation by over $100 \%$ in castor bean infected with A. tumefaciens and the mechanism of secondary tumor initiation is similar to that of primary tumor initiation.

On the other hand, IAA, GA3, ABA and $\mathrm{CK}$ showed differentiation in production amount through gall formation development. In transformation period (transformed the normal cell to primary tumor cell through 7 days from inoculation) activators growth regulators IAA, GA3 and CK were decreased but inhibitor growth regulators $\mathrm{ABA}$ was increased.

In the duplication period (primary tumor cell increased and transformed to tumor mass after 15 days from inoculation) activator growth regulators were increased, and inhibitor was decreased at this stage up to 30 days from inoculation.

The organization and differentiation period (the crown gall tumor after 45 days from inoculation) the IAA and $\mathrm{CK}$ were continuous increased but GA3 and ABA decreased. Also, CK was increased in the infected plants at all stages compared with the control. These periods of crown gall development and formation were agreement with the recorded by Klein (1962).

Results obtained improved that the production of IAA and CK and the imbalance in their ratio were leading to the development of tumors and gall formation. Also, cytokinins play a crucial role in the tumor development. These results as previously recorded by many investigators (Matveeva et al., 2004, Liu and Nester 2006, Alekseeva et al., 2008 and Kamada-Nobusada and Sakakibara 2009). Also, GA3 ratio play a role in A. tumefaciens aggressiveness but through gall information whereas, it was increased in the first period then decreased. These results were recorded also by Gong and Gao (2008).

It is well known that balanced fertilization is one of the important means for controlling plant diseases. In this study, the effect of N, P and K fertilization either alone or in combination on the severity of crown gall disease, plant growth and plant uptake of nutrients was investigated. Generally, mineral fertilizer treatments in the plants decreased the severity and development of the crown gall disease. Thus, they reduced the number of galls compared with control and also gall index (GI) which can be determine and taken as a criterion of the severity of infection. Potassium fertilizer alone or in combination with nitrogen resulted in the higher reduction in the number of galls. Gall index (GI) varied with some fertilizers or their combinations such as (K), (NP) and (KP) compared with control receipting no fertilizers. The lowest GI was in a balanced fertilizer treated plants with (NPK) followed by combination. No significant results were noticed in the weight of galls in all fertilizer treatments. From these results, it can be indicated that fertilizer treatments have decreased the number of galls per plant even though the unfertilized plants have a high gall formation. So, mineral fertilization especially in combination of (NPK and NP) could decrease gall formation on the infected plants compared with control. A similar result was reported by Florenzano (1946) and Hussin and Deep (1965). Nitrogen fertilizer, increased the susceptibility of plants to crown gall, was evidenced by the high incidence of gall formation. This was because of nitrogen

Egypt. J. Phytopathol., Vol. 39, No. 1 (2011) 
in increasing the vegetative growth and rendering the tissue succulent increasing disease severity, which was explained by Abd-El-Hafez et al., (1975), who reported a substantial decrease in fresh and dry weight of shoots in infected plants treated with (N) and (NP). These data are the same of our results. The highest fresh and dry shoots resulted in the fertilizer combination NPK and compost treatments.

The fresh and dry weight of roots showed significant differences than the control, nitrogen in combination with phosphorus (NP) application decreased fresh and dry weigh of roots and the highest one resulted from NPK with compost fertilizers compared with the control.

The effect of fertilizers and inoculation with A. tumefaciens on mineral composition of plants showed that all fertilization increased the $\mathrm{N}$ uptake in plants compared with the control. The highest one was recorded in $(\mathrm{N})$ and (NPK with compost) treatments. As well as $\mathrm{P}$ fertilizer showed an increase in uptake recorded in the combination fertilizers (NPK with compost) compared with control while it was decrease in plants treated with $(\mathrm{P})$ alone. The plants treated with $(\mathrm{K})$ showed highest uptake in (NPK) combination fertilizer while it was decrease in treatment with $\mathrm{K}$ alone.

\section{Conclusion}

These results proved that combination between fertilizers (NPK with compost) has increased plant growth which may be due to the decrease in disease severity and gall development. These results are in accordance with phase of Zavalin et al., (2003).

\section{References}

Abd-El-Aziz, R.M. 2004. Pathological and biological studies on crown gall disease of stone fruits. M. Sc. Thesis. Fac. of Agric. Cairo Univ. Pp97.

Abd-El-Hafez, A.M.; Taha, S.M.; Mahmoud, S.A.Z. and Tawfik, A.E. 1975. Effect of manuring on the severity of crown gall disease caused by Agrobacterium tumefaciens (Sm. and Town.) Conn. Egypt. J. Microbiol., 10(1-2): 115-124.

Alekseeva, V.V.; Rukavtsova, E.B.; Golubchikova, Yu.S. and Buryanov, Ya.I. 2008. Inhibition of agrobacterial oncogene expression by means of antisense RNA. Mole. Biol., (New York), 42(1): 153-157.

Anand, V.K.; Bauer, C. and Heberlein, G.T. 1975. Effect of gibberellic Acid on crown gall tumor induction in aging primary pinto bean leaves. Plant Physiol., 55(6):1016-1017.

AOAC. 1995. Methods of Analysis. Association of Official Agriculture of Chemists. $16^{\text {th }}$ ed, Washington D. C. USA.

Barakat, F.M.; Mikhail, M.S.; Tawfik, A.E. and Abd-El-Aziz, R.M. 2009. Detection of variation in Egyptian isolates of Agrobacterium tumefaciens. Egypt. J. Phytopathol., 37(2): 117- 131. 
Braun, A.C. 1952. Conditioning of the host cell as a factor in the transformation process in crown gall. Growth., 16: 65-74.

Brencic, A.; Eberhard, A. and Winans, S.C. 2004. Signal quenching, detoxification and mineralization of vir gene-inducing phenolics by the $\mathrm{VirH} 2$ protein of Agrobacterium tumefaciens. Molecular Microbiology, 51(4): 1103-1115.

Brencic, A.; Angert, E.R. and Winans, S.C. 2005. Unwounded plants elicit Agrobacterium vir gene induction and T-DNA transfer: transformed plant cells produce opines yet are tumor free. Molecular Microbiology, 57(6): 1522-1531.

ElKhalifa, M.D. and Yousif, A.M. 1974. Crown gall on castor bean leaves III. Some quantitative aspects of secondary tumour initiation. Physiol. Plant Pathol., 4(4): 435-442.

El-Merzabani, M.M., El-Aaser, A.A. and Zakhary, N.I. 1977. Determination of inorganic phosphorus in serum. J. Clin. Chem. Clin. Biochem., 15(12): 715-718.

Florenzano, G. 1946. Effect of nitrogenous fertilizers on castor bean galls caused by B. tumefaciens. Intern. Bull. Plant. Protect., 20: 97 (c.f., Biol. Abst., 23: 30270, 1949).

Gabibov, M.A. 2006. Productivity of green matter of maize depending on use of bacterial fertilizers. Kukuruza i Sorgo, 4:12-13.

Gong, Y and Gao, F. 2008. Effects of Agrobacterium tumefaciens on the physiological and biochemical properties in sweet potato explants. Scientia Agricultura Sinica, 41(6): 1649-1654.

Hildebrand, E.M. 1942. A micrurgical study of crown gall infection in tomato. Jour. Agr. Res., 65: 45-59.

Hussin, H.M. and Deep, I.W. 1965. Effect of mineral nutrition on development of crown gall on Bonny Best tomato and Mazzard Cherry. Phytopathology, 55: 575- 581.

Kamada-Nobusada, T. and Sakakibara, H. 2009. Molecular basis for cytokinin biosynthesis. Phytochemistry. 70 (4): 444-449.

Klein, R.M. 1962. Mechanisms of crown gall induction. In: "Abnormal and Pathological Plant Growth" ( $3^{\text {rd }}$ Eds. Sparrow, A. H.; Caldecott, R. S.; Curtis, H. J. and Koshland, M. E. eds.), Associated Universities, Inc., New York, USA. pp. 97-114.

Li, L.; Tan, B.; Yu W.; Ishiguro, Y.; Fukui, H.; Kageyama, K. and Matsumoto, S. 2008. Observation of attachment of Agrobacterium tumefaciens to rose cell surface using TEM in relation to resistance responses to crown gall disease. Acta Horticulturae, 767: 451-456.

Liu, P. and Nester, E.W. 2006. Indoleacetic acid, a product of transferred DNA, inhibits vir gene expression and growth of Agrobacterium tumefaciens C58. PNAS. USA. 103(12): 4658-4662.

Egypt. J. Phytopathol., Vol. 39, No. 1 (2011) 
Matthysse, A.G. and McMahan, S. 2001. The effect of the Agrobacterium tumefaciens attR mutation on attachment and root colonization differs between legumes and other dicots. Appl. and Environ. Microbiol., 67(3): 1070-1075.

Matveeva, T.V.; Frolova, N.V.; Smets, R.; Dodueva, I.E.; Buzovkina, I.S.; Onckelen, H. van and Lutova, L. A. 2004. Hormonal control of tumor formation in radish. $J$. Pl. Grow. Reg., 23(1): 37-43.

Murat, A.B.; Colak, S.; Akca, Y. and Genc, C. 2007. Effect of fertilizer rate on the growth, yield and fruit characteristics of dried apricot (cv. Hacihaliloglu). Asian J. Plant Sci., 6(2): 294-297.

Pasynkov, A.V. 2002. Effect of cereal seeds dressing by nitrogen fixing preparations on productivity and seed quality. Agrokhimiya, 10: 41-47.

Prakash, L. and Prathapasenan, G. 1990. NaCl and gibberellic acid- induced changes in the content of auxin and the activities of cellulose and pectin lyase during leaf growth in rice (Oryza sativa). Anna. of Bot. 65: 251- 257.

Snedecor, R. G. and Cochran, W. G. 1980. Statistical methods. Sixth edition, Iowa State Univ. Press, Amer. Iowa, USA.

Tan, B.S.; Ishiguro, Y.; Kageyama, K.; Matsumoto, S. and Fukui, H. 2005. Blocking of attachment to cell wall as a resistance response to crown gall bacteria Agrobacterium tumefaciens by roses. Journal of the Japanese Society for Horticultural Science, 74(4): 324-329.

Veselov, D.; Langhans, M.; Hartung, W.; Aloni, R.; Feussner, I.; Gotz, C.; Veselova, S.; Schlomski, S.; Dickler, C.; Bachmann, K. and Ullrich, C.I. 2003. Development of Agrobacterium tumefaciens C58- induced plant tumors and impact on host shoots are controlled by a cascade of jasmonic acid, auxin, cytokinin, ethylene and abscisic acid. Planta, 216(3): 512-522.

Wise, A.A.; Voinov, L. and Binns, A.N. 2005. Intersubunit complementation of sugar signal transduction in VirA heterodimers and posttranslational regulation of VirA activity in Agrobacterium tumefaciens. Journal of Bacteriology, 187(1): 213-223.

Zavalin, A.A.; Dukhanina, T.M.; Khusainov, Kh. A.; Lyalichkin, O.A.; Sokolov, V.A.; Tarasov, A.L.; Novoselov, S.I. and Evdokimova, M.A. 2003. Effect of fertilizers and biopreparations on productivity of barley cultivars. Agrokhimiya. 1: 30-37.

Corresponding author: Abd-El-Aziz, R.M.

E-mail: rab.m.sultan@gmail.com 


$$
\begin{aligned}
& \text { دور بعض العوامل المؤثرة على تطور مرض التدرن التاجى } \\
& \text { فاروق عحم بركات1 ، موريس صبرى ميخائيل1 ،على السيد توفيق } 2 \text { ،و } \\
& \text { رباب عمه عبد العزيز } \\
& \text { 1- قسم أمر اض النبات ، كليه الزر اعة ، جامعه القاهرة ، مصر. }
\end{aligned}
$$

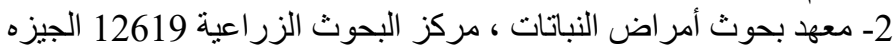

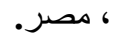

الجروح و اختلاف اعماقهاو ميعاد اجراء التلقيح بميكروب التدرن التاجى فى في

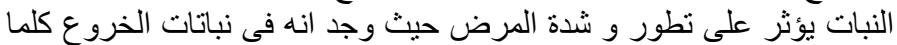

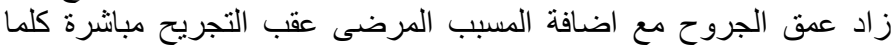

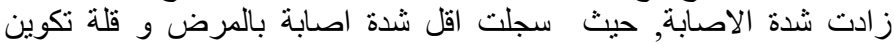

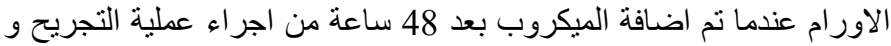

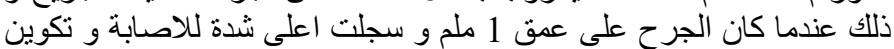

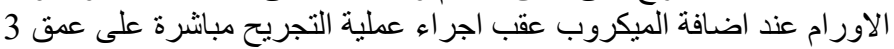
ملم يليها على عمث 5 ملم. فى نبات المشمش وجد ان النما الهرمونات النباتية حمض اندول اسيتيك و

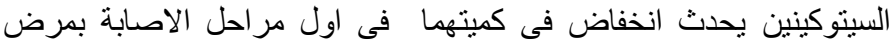

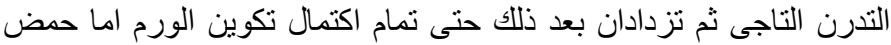

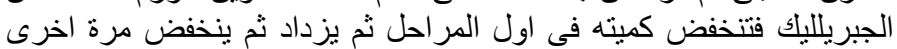

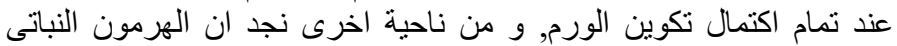

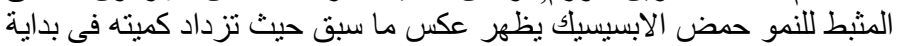
تكون الورم ثم يحدث لكميته انخفاض فى المراحل التالية حتى تمام اكتمال

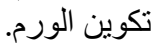

ايضا تختلف كمية منظمات النمو المختلفة سوراء منشطة للنمو او مثبطة له اله (حمض اندول اسيتيك, السيتوكينين, حمض الجبريلليك وحمض الإبك الابسيسيك) و

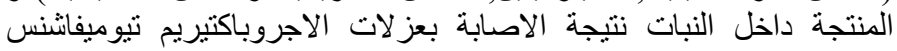

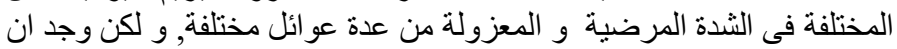

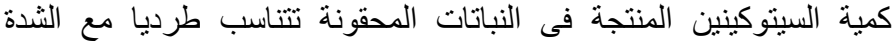

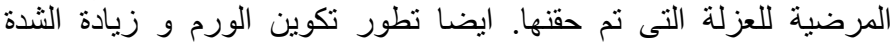

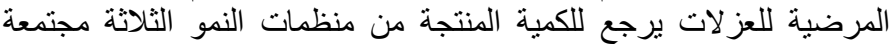

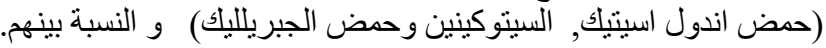

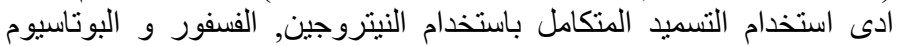

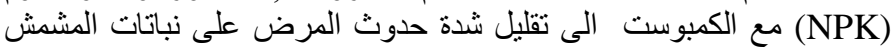

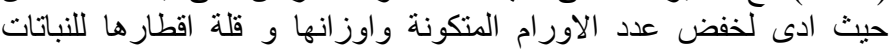

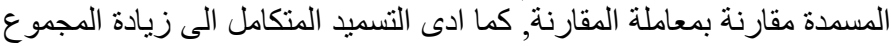

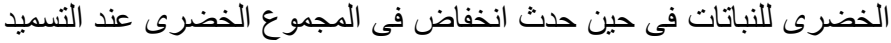

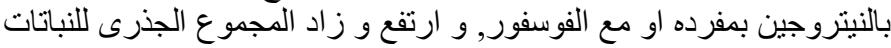

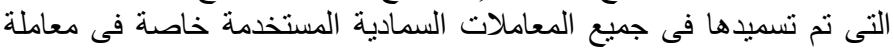

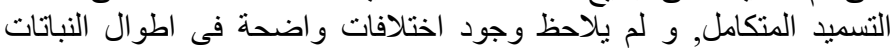

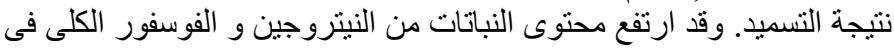

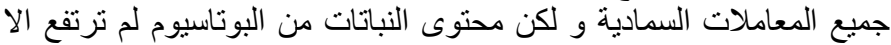

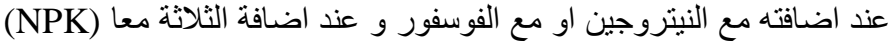

Egypt. J. Phytopathol., Vol. 39, No. 1 (2011) 